\author{
AUS DEM LEHRSTUHL FÜR \\ MUND- KIEFER- GESICHTSCHIRURGIE \\ DIREKTOR: PROF. DR. DR. THORSTEN E. REICHERT \\ DER FAKULTÄT FÜR MEDIZIN \\ DER UNIVERSITÄT REGENSBURG
}

\title{
EGR1 SUPPORTS THE OSTEOGENIC DIFFERENTIATION OF DENTAL STEM CELLS
}

\author{
Inaugural - Dissertation \\ Zur Erlangung des Doktorgrades \\ der Zahnmedizin
}

der

Fakultät für Medizin

der Universität Regensburg

vorgelegt von:

Thomas Preß 



\author{
AUS DEM LEHRSTUHL FÜR \\ MUND- KIEFER- GESICHTSCHIRURGIE \\ DIREKTOR: PROF. DR. DR. THORSTEN E. REICHERT \\ DER FAKULTÄT FÜR MEDIZIN \\ DER UNIVERSITÄT REGENSBURG
}

EGR1 SUPPORTS THE OSTEOGENIC DIFFERENTIATION OF DENTAL STEM CELLS

\author{
Inaugural - Dissertation \\ Zur Erlangung des Doktorgrades \\ der Zahnmedizin
}

der

Fakultät für Medizin

der Universität Regensburg

vorgelegt von:

Thomas Preß 
Dekan: Prof. Dr. Dr. Thorsten E. Reichert

1. Berichterstatter: PD Dr. Christian Morsczeck

2. Berichterstatter: PD Dr. Kerstin Galler

Tag der mündlichen Prüfung: 14.4.2015 


\section{Inhaltsverzeichnis}

- Einleitung

- Material und Methoden

- Ergebnisse

- Osteogene Differenzierung induziert EGR1

- EGR1-Herunterregulierung inhibiert DLX3 und BMP2

- EGR1-Überexprimierung unterstützt die Mineralisierung und verstärkt die Expression von DLX3 und BMP2

- Diskussion

- Schlussfolgerung

- Literaturverzeichnis

- Originalpublikation

- Abstract

- Introduction

- Materials and methods

- Results

- Discussion

- References

- Lebenslauf 


\section{Einleitung}

Diese Studie beschäftigt sich mit dem Einfluss des Transkriptionsfaktors early growth response gene 1 (EGR1) auf die osteogene Differenzierung dentaler Stammzellen.

Aus früheren Studien ist bekannt, dass Stammzellen, welche von der Neuralleiste abstammen, auch im Bereich der Zahnmedizin für Geweberegeneration genutzt werden können [1]. Als Quelle dieser Stammzellen können demnach die durch Zahnärzte oft prophylaktisch extrahierten Zähne dienen. Seit dem Jahr 2000 ist es möglich, diese Stammzellen aus entfernten Weisheitszähnen und deren Zahnfollikeln zu gewinnen [2,3]. Für die effektive klinische Anwendung von stammzell-basierten Therapien ist es jedoch wichtig, die grundlegenden molekularbiologischen Mechanismen dieser Zellen $\mathrm{zu}$ verstehen. Bisher bekannte Regulierungen werden im Folgenden genauer beschrieben.

Osteogenese wird in Knochenmarksstammzellen (bone marrow stromal cells (BMSCs)) durch die knochenmorphogenetischen Proteine (bone morphogenetic proteins (BMP)), speziell durch BMP2 induziert [4]. Die Transkriptionsfaktoren, run-related transcription factor 2 (RUNX2), distal-less homebox 3 (DLX3) und specificity protein 7 (SP7, Osterix), stellen Zielgene von BMP2 dar [5-7]. Vor 2 Jahren konnte eine Studie zeigen, dass DLX3 und BMP2 ihre Genexpression in dentalen Follikelzellen (DFCs) gegenseitig regulieren [8]. Eine weitere Möglichkeit Osteogenese $\mathrm{zu}$ induzieren, stellt die Behandlung der Zellkultur mit Dexamethason dar [9]. In diesem Fall kommt es zu einer erhöhten Alkalische PhosphataseAktivität (ALP) und verstärkten Mineralisierung in DFCs im Vergleich zu einer Osteogenese durch BMP2. BMP2 bewirkt hingegen eine stärkere Hochregulierung der osteogenen Markergene, als dies bei der Behandlung mit Dexamethason der Fall ist.

Microarray-Studien mit DFCs konnten zeigen, dass nach induzierter osteogener Differenzierung mittels osteogenem Differenzierungsmedium (ODM), BMP2 oder auch insulin-like growth factor 2 (IGF2), die Expression des Transkriptionsfaktors EGR1 hochreguliert war [10]. Dies konnte auch nach DLX3-Überexpression beobachtet werden [8]. EGR1 wurde bereits in früheren Studien als Transkriptionsfaktor dargestellt, welcher für Wachstum und Proliferation, sowie als Regulator verschiedenster biologischer Prozesse essentiell ist [11,12]. Auch bei Wundheilungsprozessen von Gefäßen, Knorpel und Knochen scheint EGR1 eine wichtige Rolle zu spielen [13-15]. Im Bezug auf den kortikalen Knochen 
konnte gezeigt werden, dass eine Herunterregulierung von EGR1 in immunsuppremierten Mäusen Strukturveränderungen bewirkt [16]. Dies könnte darauf hindeuten, dass EGR1 wichtig für die allgemeinen Knocheneigenschaften ist und ein mögliches Zielgen für tissue engeneering darstellt [17].

Die vorliegende Studie beschäftigte sich deshalb mit der Fragestellung, ob und wie EGR1 die osteogene Differenzierung in dentalen Stammzellen beeinflusst.

\section{Materialien und Methoden}

In dieser Studie wurde der Einfluss von EGR1 auf die osteogene Differenzierung dentaler Stammzellen unter Zuhilfenahme von Zellkulturen untersucht. Die osteogene Differenzierung wurde durch Zugabe von Dexamethason oder BMP2 in dem Zellkulturmedium eingeleitet. Die Hochregulierung von EGR1 wurde durch Transfektion eines entsprechenden Expressionsplasmids, die Herunterregulierung mittels spezifischer siRNA erreicht. Die Genexpression wurde auf RNA-Ebene mittels quantitative reverse transcription-polymerase chain reaction (qRT-PCR) und auf Proteinebene mittels Western Blot analysiert. Das osteogene Differenzierungsverhalten wurde durch Quantifizierung der Biomineralisierung untersucht. Detaillierte Informationen $\mathrm{zu}$ den angewendeten Materialien und Methoden können der anhängenden Originalpublikation entnommen werden.

\section{Ergebnisse}

\section{Osteogene Differenzierung induziert EGR1}

Um die Expression von EGR1 während der osteogenen Differenzierung in SCAPs zu untersuchen, wurden diese mit ODM oder BMP2 behandelt. Nach 3 Tagen osteogener Differenzierung konnte die Expression von EGR1 gesteigert werden. Diese Zunahme war in ODM-behandelten geringfügiger vorhanden als in BMP2-behandelten SCAPs (Abb. 1). 

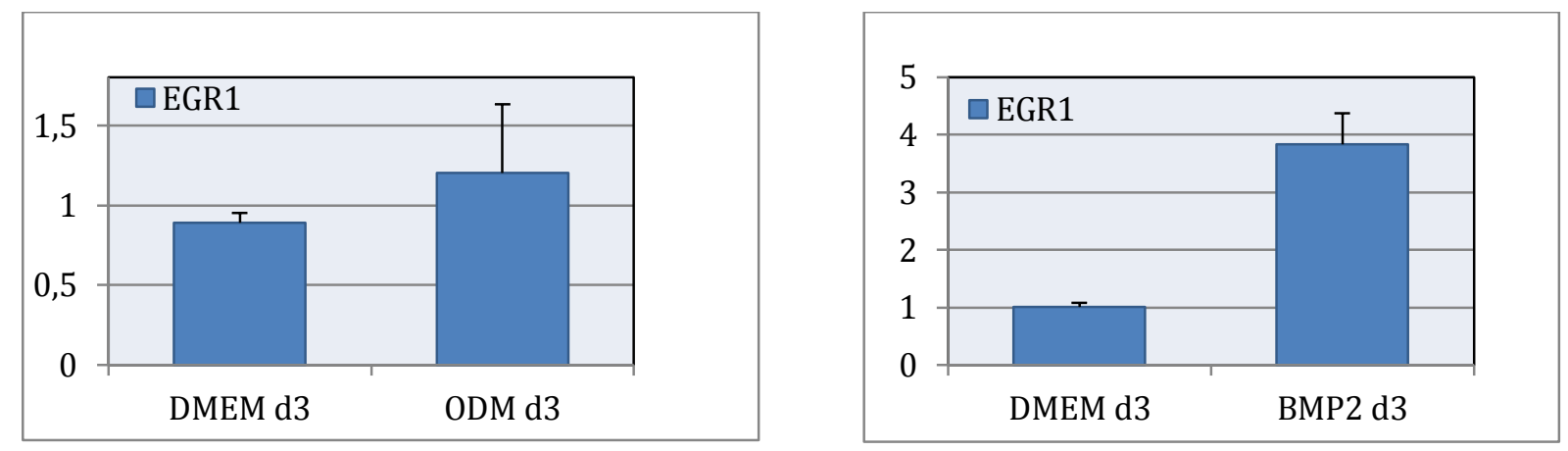

Abbildung 1 ODM- \& BMP2-Medium induziert die EGR1 Expression (SCAP). Die Genexpression wurde mittels quantitative reverse transcription-polymerase chain reaction (qRT-PCR) nach 72 Stunden osteogener Differenzierung bestimmt.

\section{EGR1-Herunterregulierung inhibiert DLX3 und BMP2}

Durch Herunterregulierung von EGR1 mittels spezifischer siRNA wurde der Einfluss von EGR1 auf die osteogenen Markergene sowohl in SCAPs, als auch in DFCs untersucht. In SCAPs konnte EGR1 so um 75 Prozent, in DFCs um 85 Prozent, herunterreguliert werden (Abb. 2A \& 2B).

\section{$\mathbf{A}(\mathrm{DFC})$}

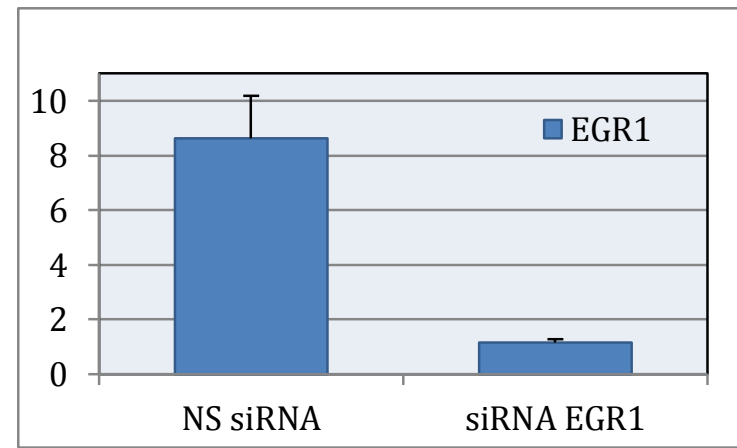

\section{B (SCAP)}

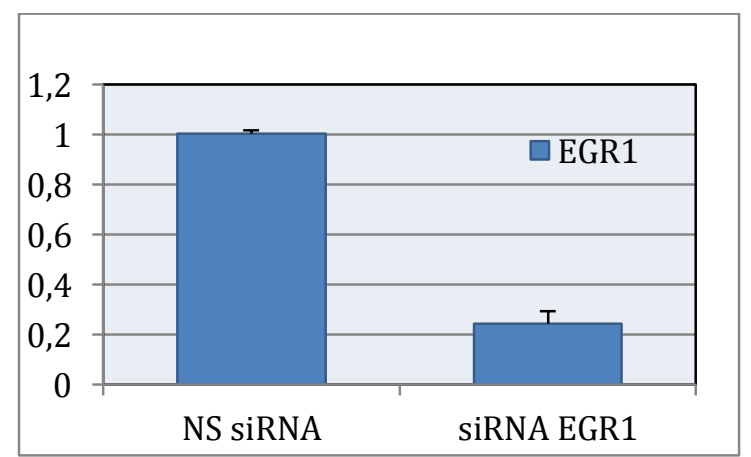

Abbildung 2 qRT-PCRs zeigen die Expression von EGR1 48 Stunden nach Transfektion der EGR1-spezifischen siRNA (siRNA EGR1) im Vergleich zu der unspezifischen siRNA (NS siRNA) in SCAPs (A) sowie DFCs (B).

Die osteogenen Differenzierungsmarkergene DLX3, BMP2 und ALP waren nach EGR1Herunterregulierung sowohl in SCAPs als auch in DFCs signifikant herunterreguliert. RUNX2 zeigte eine geringfügige Hochregulierung (Abb. 3A \& 3B). 


\section{A (SCAP)}

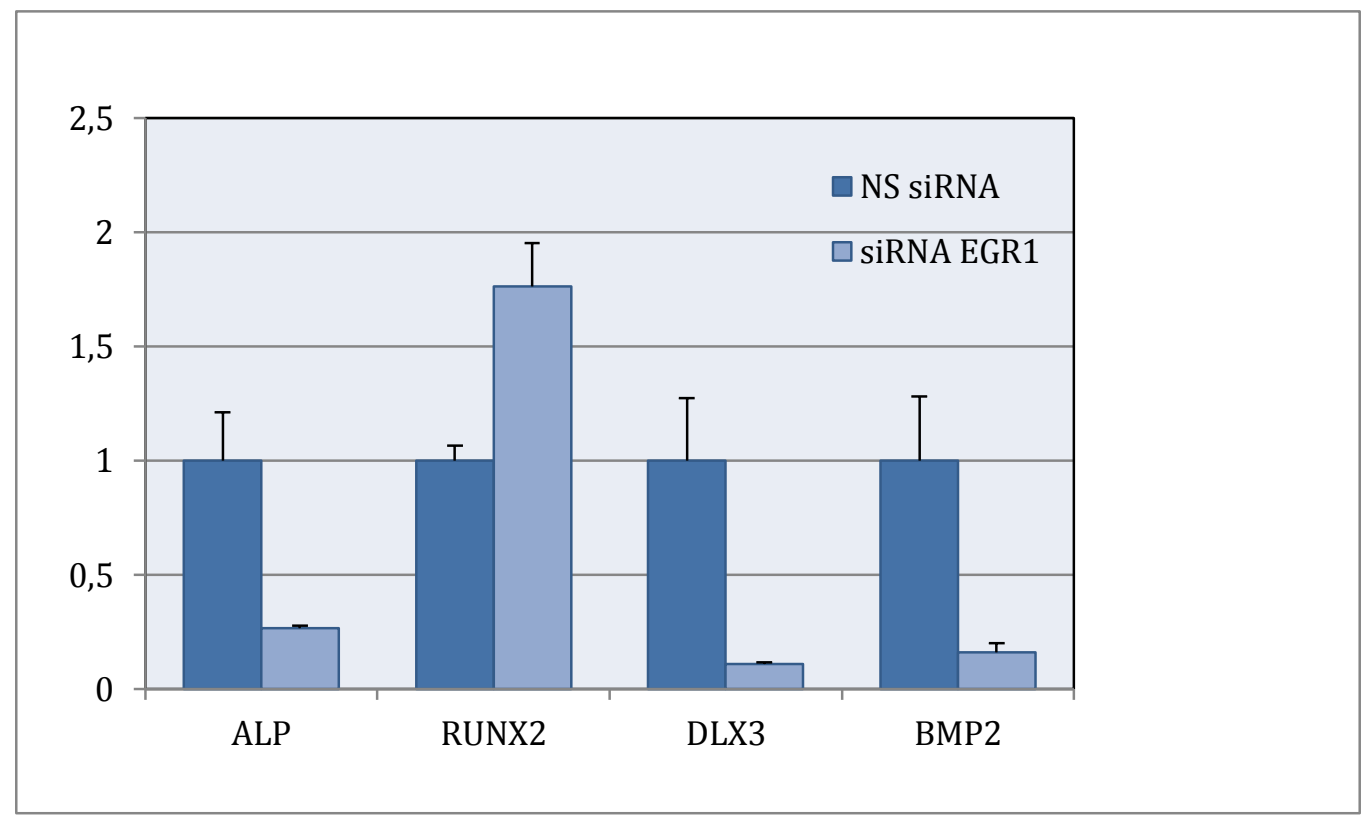

\section{B (DFC)}

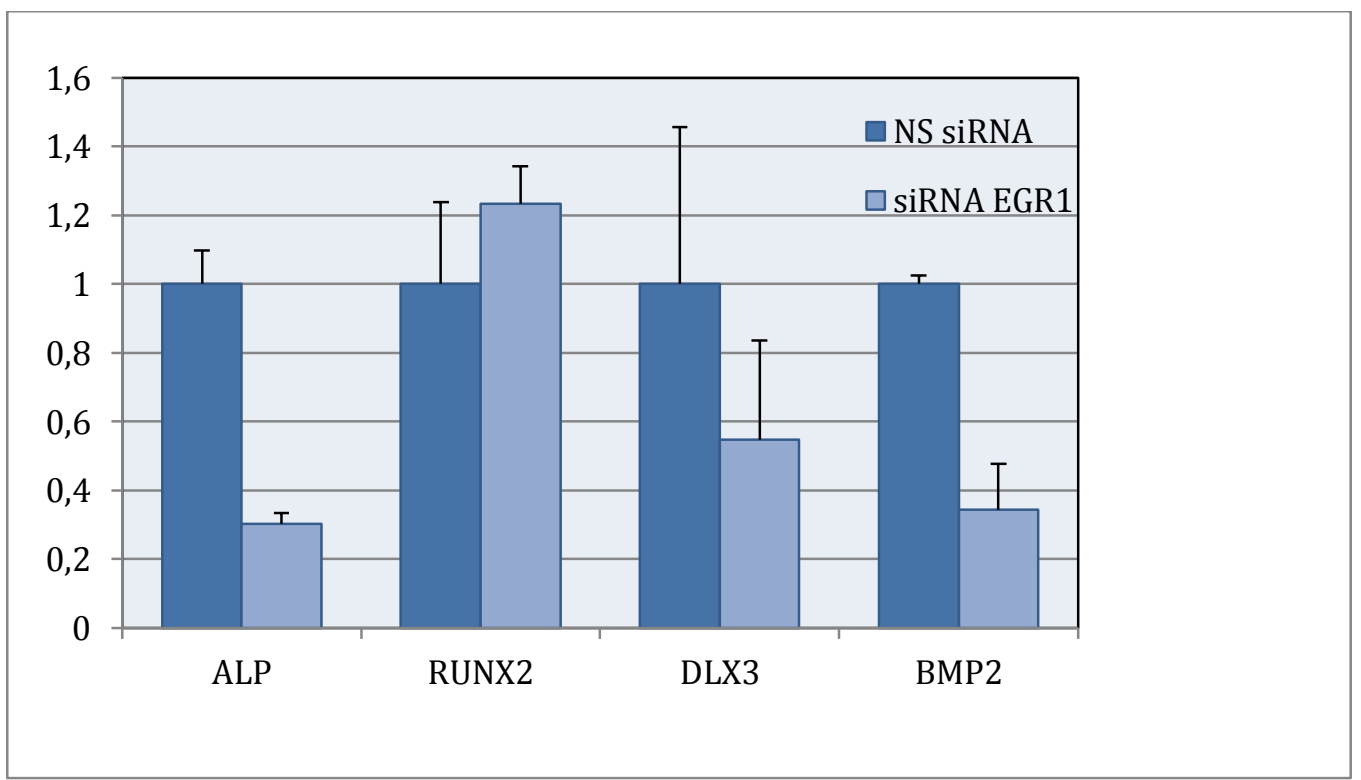

Abbildung 3 qRT-PCRs zeigen die Expression der osteogenen Markergene ALP, RUNX2, DLX3 und BMP2 48 Stunden nach Transfektion der EGR1 spezifischen siRNA. Die unspezifische siRNA wurde zur besseren Vergleichbarkeit auf den Wert 1 kalibriert.

EGR1-Überexprimierung unterstützt die Mineralisierung und verstärkt die Expression von DLX3 und BMP2 
Um die Auswirkung von EGR1 auf die Biomineralisierung von SCAPs zu untersuchen, wurden SCAPs mit einem Expressionsplasmid (pEGR1) transfiziert. Dadurch konnte eine 14fache Hochregulierung von EGR1 erzielt werden (Abb. 4).

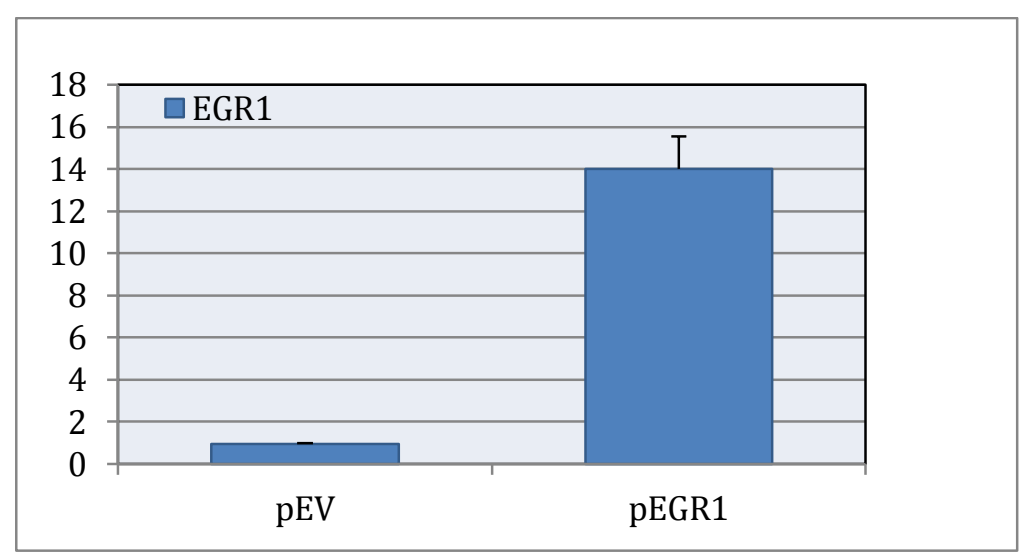

Abbildung 4 qRT-PCRs zeigen die Expression von EGR1 48 Stunden nach Transfektion des Plasmids (pEGR1) im Vergleich zu einem Leervektor (pEV).

Zur Bestimmung der Mineralisierung der SCAPs nach EGR1-Überexpression wurde eine Alizarin-Färbung (siehe Originalpublikation) sowie eine Quantifizierung dieser durchgeführt. Eine stärker ausgeprägte Biomineralisierung konnte in EGR1-überexprimierten SCAPs im Vergleich zu den mit einem Leervektor transfizierten Zellen beobachtet werden. Dies war sowohl bei mit Standard- als auch mit osteogenem Differenzierungsmedium behandelten Zellen der Fall (Abb. 5).

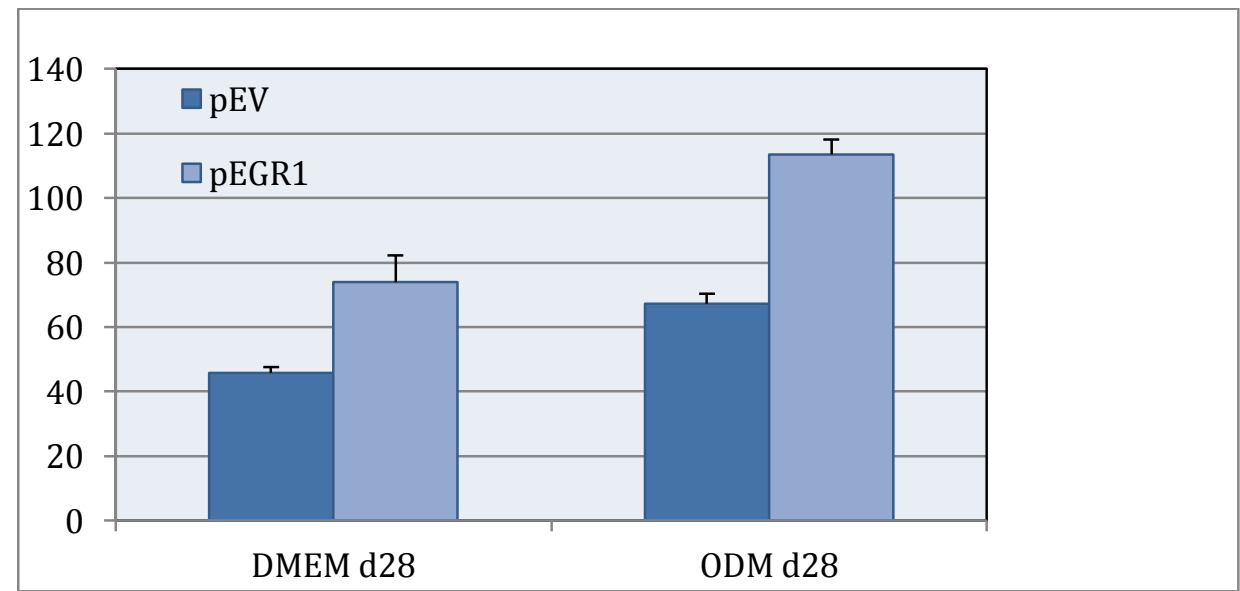

Abbildung 5 Die Quantifizierung der Alizarin-Färbung. Die dunklen Balken repräsentieren die SCAPs, welche mit dem Leervektor, die hellen Balken jene, welche mit dem EGR1-Expressionsplasmid behandelt wurden. 
Bei der Analyse der osteogenen Markergene nach EGR1-Überexpression wurde eine Hochregulierung von DLX3 und BMP2 deutlich, während sich die Expression von ALP und RUNX2 nicht veränderte (Abb. 6).

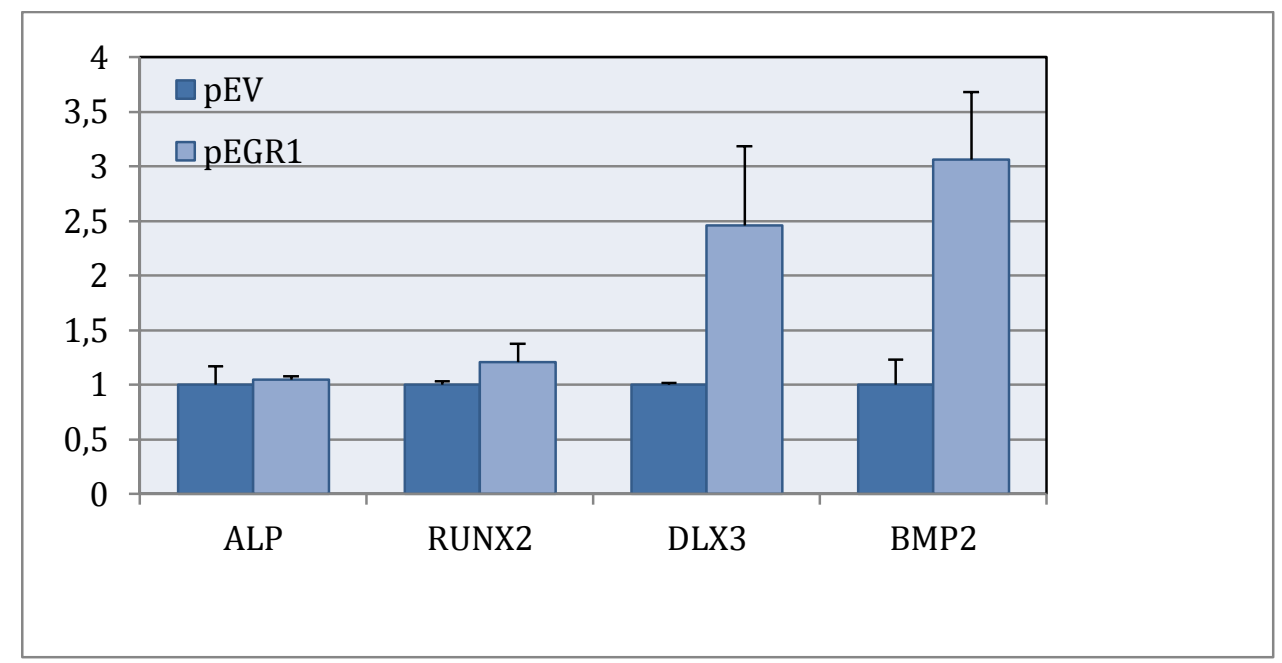

Abbildung 6 qRT-PCRs demonstrieren die Genexpression von ALP, RUNX2, DLX3 und BMP2 48 Stunden nach Transfektion des Leervektors beziehungsweise des EGR1-Plasmids.

\section{Diskussion}

Frühere Studien konnten bereits eine Hochregulierung von EGR1 nach osteogener Differenzierung mittels ODM, BMP2 und IGF2 in DFCs feststellen [10]. In dieser Studie wurde nun die Bedeutung von EGR1 auf die osteogene Differenzierung dentaler Stammzellen untersucht.

EGR1 ist ein Transkriptionsfaktor, welcher an die DNA-Sequenz GCG TGG GCG oder GCG GGG GCG bindet [18]. Diese DNA-Sequenz stellt einen Bereich dar, in dem die Promotoren vieler Zielgene liegen, welche wichtig für die Proliferation, Differenzierung, Apoptose und Wachstumskontrolle sind [19]. Diese Prozesse sind bei Gewebeheilung, wie es im Bereich der Zahnmedizin z.B. nach pulpalen, periradikulären oder ossären Erkrankungen der Fall ist, essentiell. In diesem Zusammenhang könnte EGR1 als möglicher Regulator wichtiger Zielgene eine zentrale Rolle in der Optimierung dentaler stammzellbasierter Therapien spielen. Dafür ist jedoch das Verständnis der genauen molekularbiologischen Regulierungen von besonderer Bedeutung. 
In der vorliegenden Studie stellten SCAPs und DFCs die Grundlage unserer Versuche in vitro dar. SCAPs sind Stammzellen der apikalen Papille, welche an der noch nicht vollständig ausgebildeten Wurzel eines sich entwickelnden Zahnes lokalisiert sind und besitzen ein hohes osteogenes/ odontogenes Differenzierungspotential [20,21]. DFCs können ebenso von retinierten Weisheitszähnen, respektive von dem sie umgebenden Zahnfollikel, isoliert werden. Sie sind den Stammzellen des periodontalen Ligaments (PDLSCs) ähnlich und können zur Regeneration von Alveolarknochen verwendet werden [1].

Untersuchungen konnten bereits eine verstärkte Expression von EGR1 in DFCs, die sich während der osteogenen Differenzierung befanden, zeigen [10[. Analog dazu konnte in der vorliegenden Studie auch in SCAPs eine erhöhte EGR1 Expression nach drei Tagen osteogener Differenzierung mit ODM oder BMP2 festgestellt werden. Dies lässt vermuten, dass EGR1 während der Osteogenese dentaler Stammzellen induziert ist.

In einer früheren Microarray-Studie war EGR1 auch nach DLX3-Überexpression induziert [8].

Der aktuelle Versuch zeigte, dass EGR1 in umgekehrter Weise auch DLX3 zu regulieren vermag. EGR1 reguliert neben DLX3 vermutlich auch BMP2, wohingegen ALP nicht direkt von EGR1 reguliert $\mathrm{zu}$ sein scheint. Jedoch könnte EGR1 entscheidend für die ALP Expression sein, indem andere Gene von EGR1 induziert werden, welche wiederum ALP induzieren. Genauere Regulierungsmechanismen zwischen EGR1 und ALP müssen in weiteren Studien untersucht werden. Viale-Bouroncle et al.(2012) entdeckte einen positiven DLX3-BMP2 Feedbackmechanismus während der Osteogenese in DFCs [8]. Als möglicher Regulator von DLX3 und BMP2 besitzt EGR1 auch für die klinische Therapie eine Bedeutung, wenn es als ein Zielgen für die Unterstützung der BMP2 Expression angesehen wird. In diesem Zusammenhang wurde beispielsweise gezeigt, dass BMP2 eine entscheidende Rolle bei der Osseointegration von Implantaten spielt und ein vielversprechendes Instrument für Knochenaugmentation darstellt [22,23].

Neben der Regulierung osteogener Markergene scheint EGR1 auch die Biomineralisierung dentaler Stammzellen zu unterstützen. In der vorliegenden Studie wird dies durch eine deutlich stärkere Mineralisierung der SCAPs, welche mit pEGR1 Expressionsplasmid behandelt wurden, sichtbar.

Vorhergehenden Studien konnten bereits zeigen, dass EGR1 wichtig für die Knochenheilung und Knochendichte ist, sowie Knocheneigenschaften zu regulieren vermag [24,25]. Pham et 
al.(2007) beleuchtete beispielsweise, welche wichtige Rolle EGR1 während der Zementogenese respektive der Regeneration des Periodontiums spielt [26].

\section{Schlussfolgerung}

Durch die Ergebnisse dieser Arbeit konnte gezeigt werden, dass EGR1 eine wichtige Rolle während der osteogenen Differenzierung dentaler Stammzellen spielt. EGR1 unterstützt die Biomineralisierung dentaler Stammzellen und scheint wichtige osteogene Markergene wie DLX3 und BMP2 zu regulieren. Jedoch müssen weitere Studien die genaueren regulativen Mechanismen zwischen EGR1, DLX3, BMP2 sowie ALP und deren Effekte auf die osteogene/ odontogene Differenzierung beleuchten.

\section{Literaturverzeichnis}

[1] C. Morsczeck, G. Schmalz, T.E. Reichert, F. Völlner, K. Galler, O. Driemel, Somatic stem cells for regenerative dentistry, Clin. Oral Investig. 12 (2008) 113-118.

[2] S. Gronthos, M. Mankani, J. Brahim, P.G. Robey, S. Shi, Postnatal human dental pulp stem cells (DPSCs) in vitro and in vivo, Proc.Natl.Acad.Sci.U.S.A. 97 (2000) 13625-13630.

[3] C. Morsczeck, W. Götz, J. Schierholz, F. Zeilhofer, U. Kühn, C. Möhl, et al., Isolation of precursor cells (PCs) from human dental follicle of wisdom teeth, Matrix Biol. J. Int. Soc. Matrix Biol. 24 (2005) 155-165.

[4] P. ten Dijke, J. Fu, P. Schaap, B.A.J. Roelen, Signal transduction of bone morphogenetic proteins in osteoblast differentiation, J. Bone Joint Surg. Am. 85-A Suppl 3 (2003) 34-38.

[5] A.J. Bendall, C. Abate-Shen, Roles for Msx and Dlx homeoproteins in vertebrate development, Gene. 247 (2000) 17-31.

[6] T. Komori, H. Yagi, S. Nomura, A. Yamaguchi, K. Sasaki, K. Deguchi, et al., Targeted disruption of Cbfa1 results in a complete lack of bone formation owing to maturational arrest of osteoblasts, Cell. 89 (1997) 755-764.

[7] K. Nakashima, X. Zhou, G. Kunkel, Z. Zhang, J.M. Deng, R.R. Behringer, et al., The novel zinc finger-containing transcription factor osterix is required for osteoblast differentiation and bone formation, Cell. 108 (2002) 17-29. 
[8] S. Viale-Bouroncle, O. Felthaus, G. Schmalz, G. Brockhoff, T.E. Reichert, C. Morsczeck, The Transcription Factor DLX3 Regulates the Osteogenic Differentiation of Human Dental Follicle Precursor Cells, Stem Cells Dev. (2012).

[9] S.L. Cheng, J.W. Yang, L. Rifas, S.F. Zhang, L.V. Avioli, Differentiation of human bone marrow osteogenic stromal cells in vitro: induction of the osteoblast phenotype by dexamethasone, Endocrinology. 134 (1994) 277-286.

[10] M. Saugspier, O. Felthaus, S. Viale-Bouroncle, O. Driemel, T.E. Reichert, G. Schmalz, et al., The differentiation and gene expression profile of human dental follicle cells, Stem Cells Dev. 19 (2010) 707-717.

[11] X.M. Cao, R.A. Koski, A. Gashler, M. McKiernan, C.F. Morris, R. Gaffney, et al., Identification and characterization of the Egr-1 gene product, a DNA-binding zinc finger protein induced by differentiation and growth signals, Mol. Cell. Biol. 10 (1990) 1931-1939.

[12] V.P. Sukhatme, X.M. Cao, L.C. Chang, C.H. Tsai-Morris, D. Stamenkovich, P.C. Ferreira, et al., A zinc finger-encoding gene coregulated with c-fos during growth and differentiation, and after cellular depolarization, Cell. 53 (1988) 37-43.

[13] M. Bryant, G.M. Drew, P. Houston, P. Hissey, C.J. Campbell, M. Braddock, Tissue repair with a therapeutic transcription factor, Hum. Gene Ther. 11 (2000) 2143-2158.

[14] M.-J. Guerquin, B. Charvet, G. Nourissat, E. Havis, O. Ronsin, M.-A. Bonnin, et al., Transcription factor EGR1 directs tendon differentiation and promotes tendon repair, J. Clin. Invest. 123 (2013) 3564-3576.

[15] F.L. Wang, J.R. Connor, R.A. Dodds, I.E. James, S. Kumar, C. Zou, et al., Differential expression of egr-1 in osteoarthritic compared to normal adult human articular cartilage, Osteoarthr. Cartil. OARS Osteoarthr. Res. Soc. 8 (2000) 161-169.

[16] M.K. Reumann, O. Strachna, S. Yagerman, D. Torrecilla, J. Kim, S.B. Doty, et al., Loss of transcription factor early growth response gene 1 results in impaired endochondral bone repair, Bone. 49 (2011) 743-752.

[17] M. Braddock, The transcription factor Egr-1: a potential drug in wound healing and tissue repair, Ann. Med. 33 (2001) 313-318.

[18] A.-H. Swirnoff, J. Milbrandt, DNA-Binding Specificity of NGFI-A and Related Zinc Finger Transcription Factors, Mol. Cell. Biol. 15 (1995) 2275-2287.

[19] J.-I. Pagel, E. Deindl, Early Growth Response 1--a Transcription Factor in the Crossfire of Signal Transduction Cascades, Indian J. Biochem. Biophys. 48 (2011) 226-235.

[20] W. Sonoyama, Y. Liu, T. Yamaza, R.S. Tuan, S. Wang, S. Shi, et al., Characterization of the apical papilla and its residing stem cells from human immature permanent teeth: a pilot study, J. Endod. 34 (2008) 166-171.

[21] G.T.-J. Huang, W. Sonoyama, Y. Liu, H. Liu, S. Wang, S. Shi, The hidden treasure 
in apical papilla: the potential role in pulp/dentin regeneration and bioroot engineering, $\mathrm{J}$. Endod. 34 (2008) 645-651.

[22] S.-J. Kim, H.-S. Shin, S.-W. Shin, Effect of bone block graft with rhBMP-2 on vertical bone augmentation, Int. J. Oral Maxillofac. Surg. 39 (2010) 883-888.

[23] K. Matin, H. Senpuku, N. Hanada, H. Ozawa, S. Ejiri, Bone regeneration by recombinant human bone morphogenetic protein-2 around immediate implants: a pilot study in rats, Int. J. Oral Maxillofac. Implants. 18 (2003) 211-217.

[24] S. Cenci, M.N. Weitzmann, M.A. Gentile, M.C. Aisa, R. Pacifici, M-CSF neutralization and egr-1 deficiency prevent ovariectomy-induced bone loss, J. Clin. Invest. 105 (2000) 1279-1287.

[25] M.K. Reumann, O. Strachna, L. Lukashova, K. Verdelis, E. Donnelly, A.L. Boskey, et al., Early growth response gene 1 regulates bone properties in mice, Calcif. Tissue Int. 89 (2011) 1-9.

[26] L. Pham, O. Bezouglaia, P.M. Camargo, J.M. Nervina, S. Tetradis, Prostanoids induce egr1 gene expression in cementoblastic OCCM cells, J. Periodontal Res. 42 (2007) 486-493. 


\title{
Originalpublikation
}

\section{EGR1 supports the osteogenic differentiation of dental stem cells.}

\author{
Press $\mathrm{T}^{1}$, Viale-Bouroncle S, Felthaus O, Gosau M, Morsczeck C.
}

(1) Department of Cranio-Maxillofacial Surgery, University Hospital Regensburg, Franz-Josef-Strauss-Allee 11, 93053 Regensburg, Germany

Published in: Int Endod J.

Publishing date: 21. Apr 2014 (online)

DOI: $10.1111 /$ iej.12299.

\begin{abstract}
Aim To evaluate whether and how the transcription factor early growth response gene 1 (EGR1) affects the osteogenic differentiation of dental stem cells.

Methology Dental stem cells from apical papilla (SCAPs) and from the dental follicle (DFCs) were transfected with EGR1 specific siRNA or EGR-1 expression plasmid. Gene regulation was verified at protein level by Western blotting. The expression of the transcription factors distal-less homeobox 3 (DLX3), alkaline phosphatase (ALP), and bone morphogenetic protein 2 (BMP2), which are all regulators and markers of the osteogenic differentiation in dental stem cells, was determined by quantitative reverse transcription-polymerase chain reaction (qRT-PCR). To investigate the mineralization, SCAP long term cultures were stained with alizarin red after EGR1 over-expression.

Results EGR1 was induced in SCAPs during osteogenic differentiation. DLX3 and bone morphogenetic protein 2 (BMP2) were up-regulated after EGR1 over-expression and downregulated after EGR1 depletion. The expression of ALP was also down-regulated after EGR1 depletion. The over-expression of EGR1 in SCAPs promoted mineralization after osteogenic differentiation.
\end{abstract}


Conclusions EGR1 supported the osteogenic differentiation of dental stem cells by potentially regulating the expression of DLX3 and BMP2.

Keywords: Early growth response gene 1 (EGR1), stem cells from apical papilla (SCAPs), dental follicle precursor cells (DFCs), distal-less homeobox 3 (DLX3), bone morphogenetic protein $2(\mathrm{BMP} 2)$

\section{Introduction}

Stem cells from the neural crest cell-derived dental mesoderm are possible sources for tissue regeneration (Morsczeck et al. 2008). For example, stem cells from apical papilla (SCAPs) on a carrier of hydroxylapatite produced a typical dental pulp/ dentine-like complex after transplantation into immunocompromised mice (Sonoyama et al. 2006). Guo and colleagues created a whole tooth root with dental follicle cells (DFCs) seeded on scaffolds of treated dentine matrix (TDM) (Guo et al. 2011). As a preventive measure, dentists often surgically remove wisdom teeth when they are not yet erupted or when they are retained. Since 2000 it is possible to isolate dental stem cells from wisdom teeth and the surrounding dental follicle (Gronthos et al. 2000, Morsczeck et al. 2005, Sonoyama et al. 2006). While these cells are readily available for cell-based therapies in dentistry, current research lacks knowledge about the mechanisms of dental mesenchymal stem cell differentiation. However, this knowledge is a prerequisite to profit from these kinds of stem cells in clinical therapy.

Osteogenesis in bone marrow stromal cells (BMSCs) is induced by members of the bone morphogenetic protein family (BMP), particularly by BMP2 (ten Dijke et al. 2003). BMP2 target genes comprise several homeodomain transcription factors including run-related transcription factor 2 (RUNX2), distal-less homeobox 3 (DLX3), and specificity protein 1 (SP1, osterix) (Ducy et al. 1997, Komori et al. 1997, Bendall \& Abate-Shen 2000, 
Nakashima et al. 2002). It was shown in DFCs that DLX3 and BMP2 control each other's expression during osteogenic differentiation (Viale-Bouroncle et al. 2012). In cell culture, osteogenesis can also be induced by dexamethasone (Cheng et al. 1994). Measured alkaline phosphatase (ALP) activity and mineralization in DFCs are even more profound when stimulated with dexamethasone than with BMP2 although an up-regulation of osteogenic signaling cascade genes is less pronounced (Saugspier et al. 2010). As microarray studies (GSE 20963) on DFCs indicated that the expression of early growth response gene 1 (EGR1) increases after osteogenic differentiation with osteogenic differentiation medium (ODM), BMP2 and insulin-like growth factor 2 (IGF2). The question whether and how EGR1 affects osteogenic differentiation is of particular interest (Saugspier et al. 2010). Another microarray study (GSE29753) has shown an up-regulation of EGR1 after DLX3 over-expression (VialeBouroncle et al. 2012).

Previous research indicates that EGR1 is an important transcription factor for growth and differentiation. In addition, EGR1 serves as a regulator in several biological processes (Sukhatme et al. 1988, Cao et al. 1990). Most interestingly, EGR1 contributes significantly to various tissue wound-healing processes such as healing of vessels, cartilages, and bones (Dolce et al. 1996, Bryant et al. 2000, Wang et al. 2000, Reumann et al. 2011, Guerquin et al. 2013). Reumann et al. (2011) demonstrated using EGR1 depletion in mice that EGR1 affects the structure of cortical bones. EGR1 might thus be crucial for general bone characteristics. EGR1 could also be a significant target gene for tissue engineering and alveolar bone regeneration (Braddock 2001).

This study established EGR1 depletion in SCAPs and DFCs to identify specific biological regulatory mechanisms of dental mesenchymal stem cells. Whether EGR1 over-expression in SCAPs affected mineralization was also investigated. 


\section{Materials and Methods}

\section{Dental cell culture}

Stem cells from apical papilla (SCAPs) were isolated from retained wisdom teeth of young patients with informed consent as described previously (Sonoyama et al. 2006, Akiyama et al. 2012). Dental follicle cells (DFCs), also called dental follicle stem cells (DFSCs), were purchased from AllCells@ (Alameda, Ca, USA). All cells were grown in standard basal medium, Dulbecco’s modified Eagle's medium (DMEM; Sigma-Aldrich, Munich, Germany) supplemented with $10 \%$ fetal bovine serum (FBS; Sigma-Aldrich), and $100 \mu \mathrm{g} / \mathrm{mL}$ penicillin/streptomycin. All experiments with SCAPs and DFCs were made at cell passage 6. For characterization, SCAPs and DFCs were analyzed for stem cell associated markers with flow cytometry. Isolated SCAPs expressed typical markers of progenitor cells or the stem cells CD44, CD105, and nestin (Figure 1A). DFCs expressed CD44, CD105, nestin and STRO-1 (Figure 1B). Flow cytrometry analysis for the expression of nestin in DFCs was done at passage 4; all other makers were analyzed at passage 6 .

\section{Figure 1}

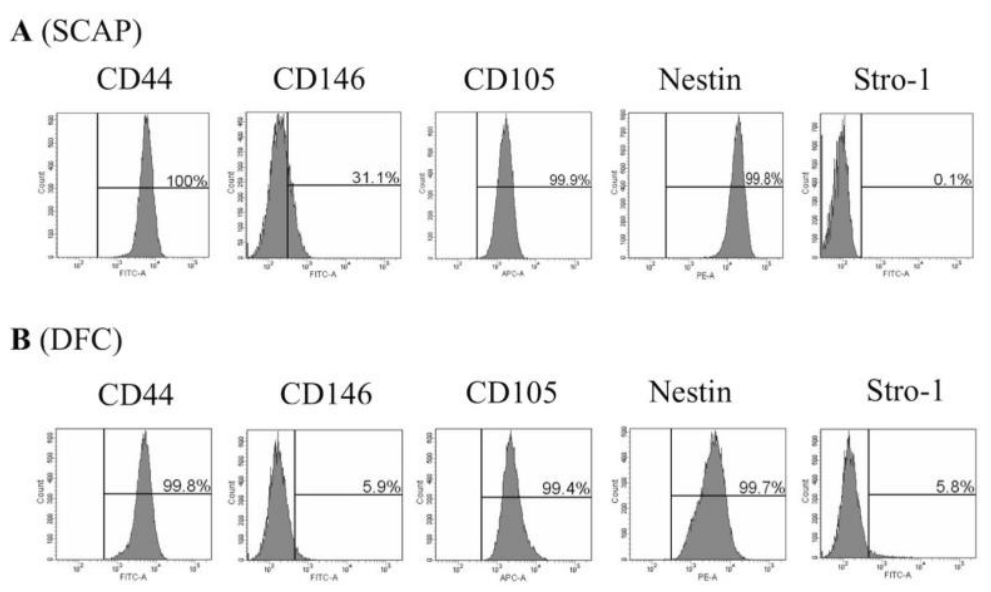

Figure 1. Flow cytometry analysis: characteristics of cultured SCAPs and DFCs (for details materials and methods). The percentage of positive cells is highlighted. SCAPs expressed CD44, CD 105 and Nestin. DFCs expressed CD44, CD 105, Nestin and Stro-1. 


\section{Osteogenic differentiation}

For osteogenic differentiation, cells were cultivated in standard medium until sub-confluence. The osteogenic differentiation medium was supplemented with dexamethasone or bone morphogenetic protein 2 (BMP2). The dexamethasone supplemented osteogenic differentiation medium (ODM) contained DMEM (Sigma-Aldrich) supplemented with 10\% FBS, $100 \mu \mathrm{mol} / \mathrm{L}$ ascorbic acid 2-phosphate, HEPES $(20 \mathrm{mmol} / \mathrm{L}), 2.8 \mathrm{mmol} / \mathrm{L} \quad \beta$ glycerophosphate and $1 \times 10^{-7} \mathrm{~mol} / \mathrm{L}$ dexamethasone sodium phosphate (Sigma-Aldrich). The BMP2-containing medium (BMP2) included DMEM (Sigma-Aldrich) supplemented with 1\% FBS (Sigma-Aldrich), 100 $\mu \mathrm{mol} / \mathrm{L}$ ascorbic acid 2-phosphate, HEPES (20 mmol/L), 2.8 mmol/L $\beta$-glycerophosphate and $50 \mathrm{ng} / \mathrm{mL}$ BMP2 (Biomol, Hamburg, Germany). As growth factors in a serum with high levels of FBS potentially mask the effect of BMP2, a BMP2 containing medium with 1\% FBS (Sigma-Aldrich) was applied. After 28 days of cell differentiation, a calcium staining was done for the evaluation of mineralization with Alizarin Red S (Sigma-Aldrich). For quantification, alizarin crystals were dissolved in $50 \mu 1$ of $10 \%$ cetylpyridinium chloride monohydrate solution (in 10mM Natrium Phosphat, $\mathrm{pH}$ 7.0) for 30 minutes. The samples were measured at $540 \mathrm{~nm}$ in a TECAN infinite F200 plate reader (TECAN, Crailsheim, Germany). Each treatment had four samples.

\section{Transfection plasmid DNA}

The transfection was done using the FuGENE® HD Transfection Reagent (Roche, Mannheim, Germany). The early growth response gene 1 (EGR1) expression plasmid pCMV6-Entry was purchased from OriGene Technologies (Rockville, Maryland, USA). An empty vector without an insert $(\mathrm{pEV})$ was used for control. The transfection was performed

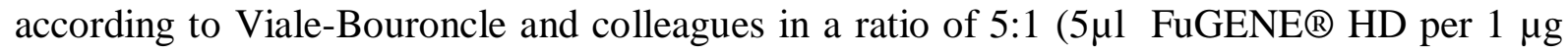
DNA) (Viale-Bouroncle et al. 2012). After 24 hours of transfection, standard basal medium 
containing antibiotics was changed into the plates. The expression of EGR1 in SCAPs was determined by quantitative reverse transcription-polymerase chain reaction (qRT-PCR) or western blotting after 48 hours. Each treatment had three samples. Previous studies confirm that the transfection efficiency is approximately 50\% (unpublished data).

\section{Transfection siRNA}

The transfection was done using the HiPerFect Transfection Reagent (Qiagen, Hilden, Germany). Four different nucleotides that target human EGR1 mRNA (GenBank No. NM_001964.2) were evaluated for EGR1 depletion in SCAPs (data not presented). 6,6 $\mu 11$ mmol EGR1 Hs_EGR1_7 FlexiTube siRNA (Cat.no. SI03078950, Qiagen) diluted in $300 \mu 1$ DMEM was used for transfection, which resulted in the best down-regulation of EGR-1.. For control, a nonspecific siRNA was used (NS siRNA; Cat.no. 1022076; Qiagen). Two days before transfection, SCAPs were seeded at a cell density of $7 \times 10^{3}$ cells per $\mathrm{cm}^{2}$. For transfection, the cells were grown until sub-confluence and cultivated in standard basal medium without fetal bovin serum and antibiotics. After 24 hours of transfection, standard basal medium containing antibiotics was changed into the plates. The expression of EGR1 in SCAPs and DFCs was determined by quantitative reverse transcription-polymerase chain reaction (qRT-PCR) or western blotting after 48 hours. Each treatment had three samples.

\section{Quantitative reverse transcription-polymerase chain reaction ( $q R T-P C R)$}

Total RNA was isolated according to the manual of the RNA isolation kit RNeasy Mini Kit (Qiagen, Hilden, Germany). For reverse transcription, the QuantiTect Reverse Transcription Kit (Qiagen) was used. To investigate gene expression of EGR1, BMP2, distal-less homeobox 3 (DLX3) and glyceraldehyde 3-phosphate dehydrogenase (GAPDH), which was used as a housekeeping gene, a quantitative PCR was done using the LightCycler® FastStart DNA 
MasterPLUS SYBR Green I (Roche). The LightCycler® TaqMan® Master was used for studying alkaline phosphatase (ALP) and run-related transcription factor 2 (RUNX2) expression. The reason for using TaqMan when studying alkaline phosphatase (ALP) and run-related transcription factor 2 (RUNX2) is that previous studies attest that TaqMan is more specific for these genes. Primer sequences are presented in table 1. PCRs were performed with the LightCycler PCR System (Roche). Quantification was done using the delta/deltacalculation-method as described by Winer et al. (1999).

\section{Western blotting}

Western blotting was performed as described by Viale-Bouroncle (Viale-Bouroncle et al. 2013). SCAPs and DFCs were harvested with trypsin and treated with lysis buffer for protein isolation (1 mM Na-Orthovanadate, $150 \mathrm{mM} \mathrm{NaCl}, 1 \mathrm{mM}$ EDTA and 1\% NP-40, ProteaseInhibitor tablets (complete mini, Roche)), solved in Tris- $\mathrm{HCl}$ with a final concentration of $20 \mathrm{mM}(\mathrm{pH} 8)$. Antibodies detecting the following proteins were used: $\beta$-Actin (AC-15; Novus Biologicals, Littleton, Colorado, USA), and EGR1 (15F7). The $\beta$-Actin antibody was used as a housekeeper standard.

\section{Statistical Analysis}

Data means and standard deviations are presented. Each treatment had 3 samples except the alizarin quantification (4 samples) per treatment. All statistical analyses were performed using Student's t test at the 5\% significance level. 


\section{Results}

\section{Osteogenic differentiation induces EGRI}

To demonstrate the role of EGR1 during osteogenic differentiation, SCAPs were treated with ODM or BMP2. The expression of EGR1 was slightly increased in ODM after three days of osteogenic differentiation in SCAPs. Significantly increased levels of EGR1 were found in BMP2 (Figure 2).

\section{Figure 2}
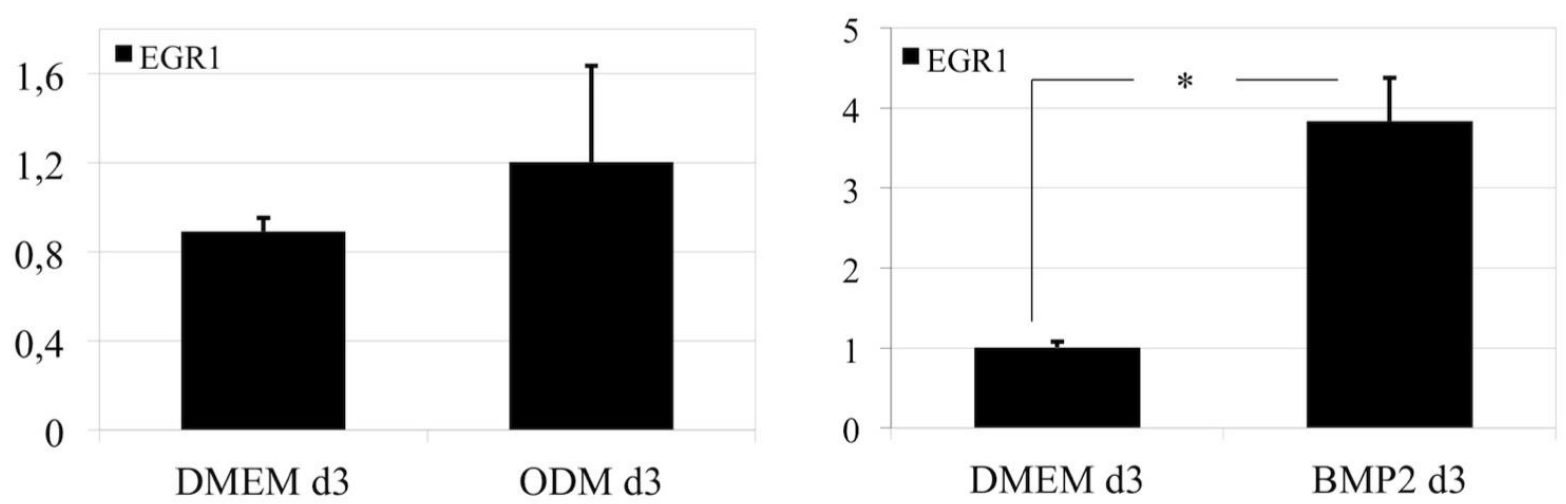

Figure 2. ODM and BMP2 medium induce EGR1 expression (SCAPs). EGR1 expression in SCAPs was measured after three days of osteogenic differentiation using ODM or BMP2 medium and was compared to DMEM standard medium using a qRT-PCR. Student's $t$ test $(*$ : $p<0.05)$.

\section{EGR1 depletion inhibits DLX3 and BMP2}

The regulation of osteogenic differentiation markers was investigated after gene silencing of EGR1 in dental stem cells. A 75 percent EGR1 knockdown was achieved by EGR1 specific siRNA in SCAPs as determined by qRT-PCR (Figure 3A). In DFCs, the knockdown efficiency was 85 percent (Figure 3B). The osteogenic differentiation markers DLX3 and BMP2 (as well as ALP) were significantly down-regulated after EGR1 depletion both in SCAPs and DFCs whereas RUNX2 was slightly up-regulated (Figure 3E, 3F). 


\section{Figure 3}

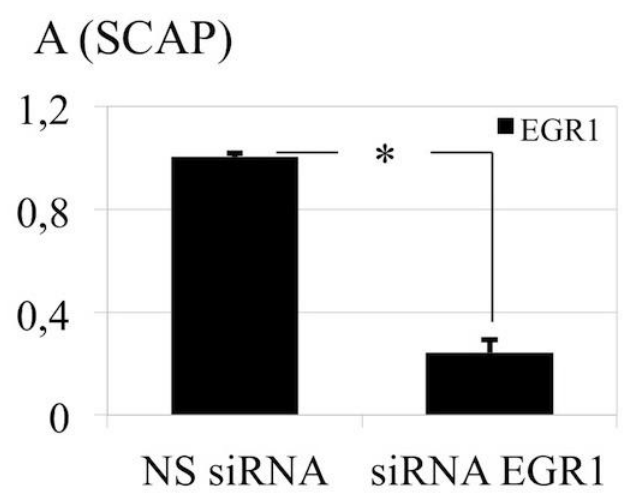

$\mathrm{C}(\mathrm{SCAP})$

\section{EGR1}

$\beta$-Actin

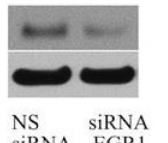

E (SCAP)

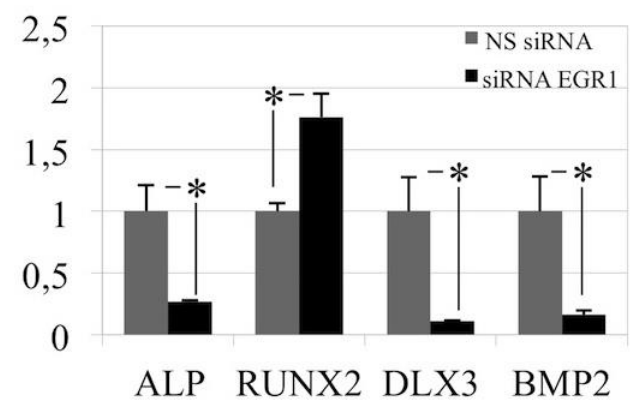

B (DFC)

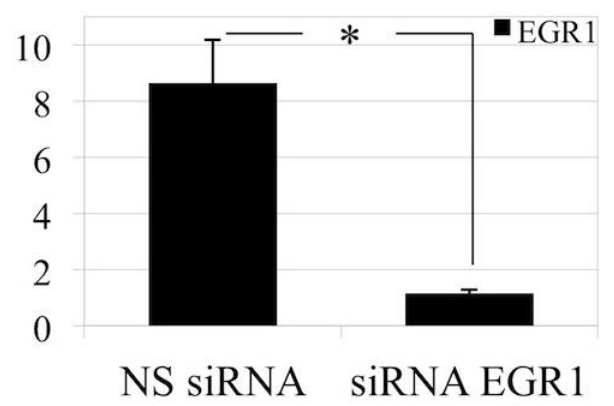

$\mathrm{D}(\mathrm{DFC})$

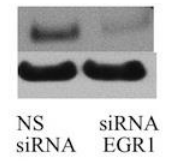

$\mathrm{F}(\mathrm{DFC})$

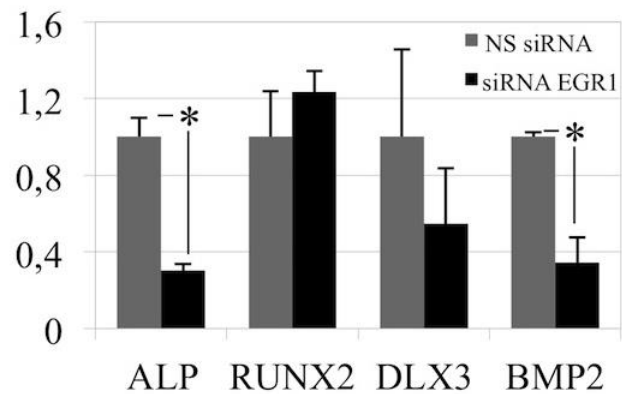

Figure 3. EGR1 depletion indicates a down-regulation of DLX3 and BMP2 (SCAPs and DFCs). (A, B) EGR1 depletion was determined by qRT-PCR analysis after 48 hours of transfection with an EGR1-specific siRNA and nonspecific NS siRNA in SCAPs and DFCs. (C, D) EGR1 expression was also verified at protein level by western blotting. (E, F) The expression of the osteogenic markers ALP, RUNX2, DLX3 and BMP2 was examined after 48 hours of transfection by a qRT-PCR. We calibrated to the nonspecific siRNA (NS siRNA) for comparison. Grey bars present nonspecific siRNA and black bars EGR1-specific siRNA. Student's t test (*: $\mathrm{p}<0.05)$.

\section{EGR1 over-expression supports mineralization and increases DLX3 and BMP2}

To demonstrate the effect of EGR1 on biomineralization in SCAPs, EGR1 over-expression was chosen because knockdown efficiency of siRNA significantly decreased three days after starting osteogenic differentiation in dental stem cells (data not presented). SCAPs were used since the regulation after EGR1 depletion was superior. In so doing, a 14-fold up-regulation 
after EGR1 over-expression was achieved. To analyze whether the over-expression of EGR1 affects the mineralization of SCAPs alizarin red staining in vitro was used. Calcium measurements were significantly increased in SCAPs with pEGR1 (Figure 4C). Investigating qRT-PCRs after EGR1 over-expression, DLX3 and BMP2 were up-regulated while the expression of ALP and RUNX2 did not change (Figure 4B).

\section{Figure 4}
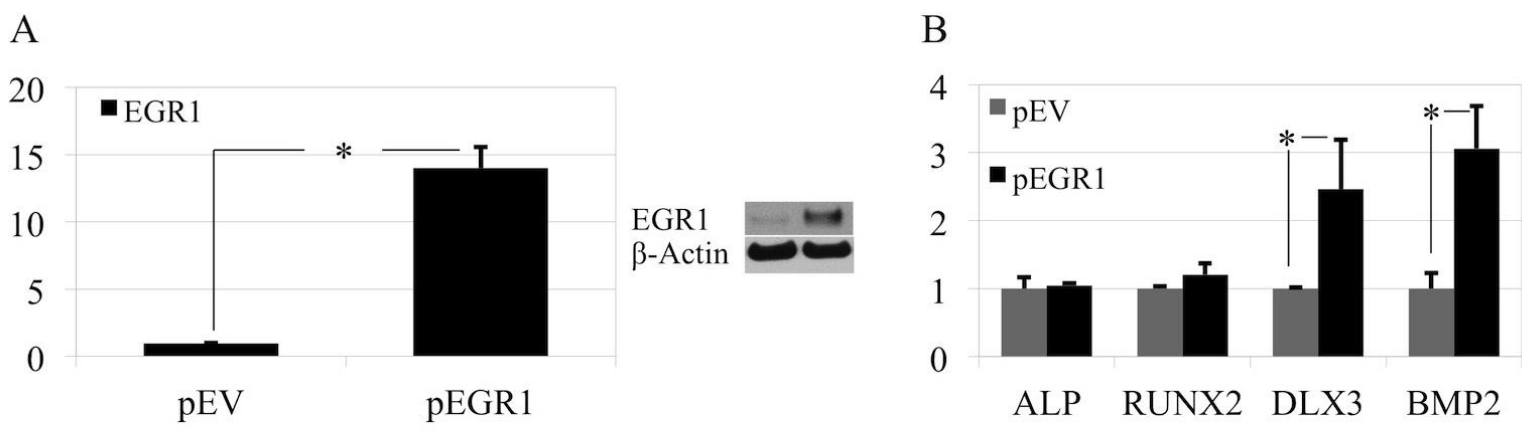

$\mathrm{C}$

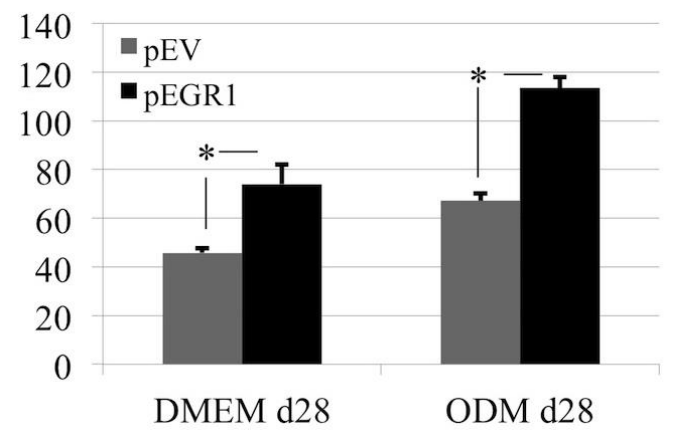

$\mathrm{D}$

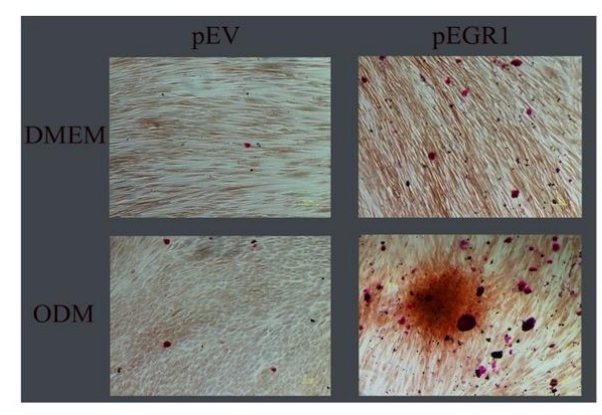

Figure 4. EGR1 over-expression indicates more mineralization after 28 days and shows up-regulation of DLX3 and BMP2 (SCAPs). (A) EGR1 over-expression was determined by qRT-PCR analysis after 48 hours of transfection with expression plasmid (pEGR1) and an empty vector (pEV). Western blot analysis confirmed EGR1 over-expression at protein level. (B) Gene expression of the osteogenic markers ALP, RUNX2, DLX3 and BMP2 was investigated after 48 hours of transfection using a qRT-PCR. Grey bars represent gene expressions transfected with an empty vector (pEV). Black bars represent gene expressions transfected with the expression plasmid (pEGR1). Total RNA, which were isolated from cells transfected with $\mathrm{pEV}$, were used for calibration. (C) Alizarin red staining: grey bars show an empty vector (pEV) and black bars the expression plasmid (pEGR1). (D) Microscopic pictures according to the column chart. Student's t test $(*: p<0.05)$. 


\section{Discussion}

Recent microarrays on DFCs documented up-regulated EGR1 levels after osteogenic differentiation with ODM, BMP2 and IGF2 (Saugspier et al. 2010). This study investigated the actual role of EGR1 during osteogenic differentiation with a special focus on the regulation of osteogenic differentiation markers.

EGR1 is a transcription factor that binds the DNA sequence GCG TGG GCG or GCG GGG GCG (Swirnoff \& Milbrandt 1995). Although current research lacks detailed knowledge about the transcriptional regulation of EGR1, it is known that this DNA sequence is an area within the promotor regions of a large number of target genes important for proliferation, differentiation, apoptosis, and growth control (for review Pagel \& Deindl 2011). These processes are fundamental for tissue regeneration, e.g. in dentistry after periradicular diseases or pulpal diseases. This also means that a thorough understanding of the transcription factor and regulator EGR could optimize dental stem cell based therapies.

The current experiments employed stem cells from apical papilla (SCAPs) and dental follicle cells (DFCs). In general, SCAPs have a high osteogenic/odontogenic differentiation potential (Huang et al. 2008, Sonoyama et al. 2008). DFCs can be isolated from retained wisdom teeth (given an immature tooth root) and are located next to the epithelial cell layer that separates dental follicle from developing dentine. DFCs are similar to periodontal ligament stem cells (PDLSCs) and can also be utilized for alveolar bone regeneration (Morsczeck et al. 2008).

Morsczeck and colleagues identified enhanced levels of EGR1 after osteogenic differentiation in DFCs (Saugspier et al. 2010). Similarly, higher levels of EGR1 were observed after three days of osteogenic differentiation with ODM and BMP2 in SCAPs. These results suggest that EGR1 is induced during the osteogenic differentiation of dental stem cells.

A recent microarray study (GSE29753) documented an EGR1 up-regulation after DLX3 overexpression in DFCs (Viale-Bouroncle et al. 2012). The experiments showed that EGR1 also 
seems to regulate DLX3. Similar to DLX3, EGR1 also regulates BMP2. In contrast, EGR1 does not seem to directly regulate ALP. However, EGR1 could be crucial for ALP-expression as it could induce other genes which in turn induce ALP. Further research is encouraged to investigate whether EGR1 supports ALP. Viale-Bouroncle et al. (2012) also found a DLX3BMP2-positive feedback mechanism during osteogenic differentiation in DFCs. The above findings also have important implications for clinical therapy.EGR1 as being a possible regulator of osteogenic differentiation could also promote a stem cells based healing process of other osseous defects such as radicular osteolysis. Since EGR1 regulates DLX3 and BMP2, EGR1 could be a target gene to support BMP2 expression. For example, recombinant BMP2 was shown to play a crucial role in osseointegration of dental implants and could be a promising instrument for vertical bone augmentation (Kim et al. 2010, Matin et al. 2003).

However, EGR1 is not only induced after osteogenic differentiation but seems to also regulate osteogenic differentiation itself. Furthermore, EGR1 supports biomineralization in dental stem cells. pEGR1 treated SCAPs revealed significantly increased levels of mineralization compared to $\mathrm{pEV}$ tested SCAPs. This is in accordance with previous studies, which indicated that EGR1 matters for bone healing, regulates bone characteristics and is important for bone density (Cenci et al. 2000, Reumann et al. 2011). For example, Pham et al. (2007) pointed out that EGR1 could be a key mediator during cementogenesis, and more generally, the regeneration of periodontium.

\section{Conclusion}

EGR1 plays a decisive role in osteogenic differentiation and supports biomineralization in dental stem cells. EGR1 induces the expression of DLX3 and BMP2. However, further research is required to shed more light on the specific biological regulations of EGR1, DLX3 and BMP2 and their effect on osteogenic differentiation. 


\section{References}

Akiyama K, Chen C, Gronthos S, Shi S (2012) Lineage differentiation of mesenchymal stem cells from dental pulp, apical papilla, and periodontal ligament. Methods in Molecular Biology NJ 887, 111-21.

Bendall A J, Abate-Shen C (2000) Roles for Msx and Dlx homeoproteins in vertebrate development. Gene 247, 17-31.

Braddock M (2001) The transcription factor Egr-1: a potential drug in wound healing and tissue repair. Annals of Medicine 33, 313-8.

Bryant M, Drew G M, Houston P, Hissey P, Campbell C J, Braddock M (2000) Tissue repair with a therapeutic transcription factor. Human Gene Therapy 11, 2143-58.

Cao X M , Koski R A, Gashler A et al. (1990) Identification and characterization of the Egr1 gene product, a DNA-binding zinc finger protein induced by differentiation and growth signals. Molecular and Cellular Biology 10, 1931-39.

Cenci S, Weitzmann M N, Gentile M A, Aisa M C, Pacifici R (2000) M-CSF neutralization and egr-1 deficiency prevent ovariectomy-induced bone loss. Journal of Clinical Investigation 105, 1279-87.

Cheng S L, Yang J W, Rifas L, Zhang S F, Avioli L V (1994) Differentiation of human bone marrow osteogenic stromal cells in vitro: induction of the osteoblast phenotype by dexamethasone. Endocrinology 134, 277-86.

Dolce C, Kinniburgh A J, Dziak R (1996) Immediate early-gene induction in rat osteoblastic cells after mechanical deformation. Archives of Oral Biology 41, 1101-8.

Ducy P, Zhang R, Geoffroy V, Ridall A L, Karsenty G (1997) Osf2/Cbfa1: a transcriptional activator of osteoblast differentiation. Cell 89, 747-54. 
Gronthos S, Mankani M, Brahim J, Robey P G, Shi S (2000) Postnatal human dental pulp stem cells (DPSCs) in vitro and in vivo. Proceedings of the National Academy of Sciences of the United States of America 97, 13625-30.

Guerquin M-J, Charvet B, Nourissat G et al. (2013) Transcription factor EGR1 directs tendon differentiation and promotes tendon repair. Journal of Clinical Investigation 123, 3564-76.

Guo W, Gong K, Shi H et al. (2011) Dental follicle cells and treated dentin matrix scaffold for tissue engineering the tooth root. Biomaterials 33, 1291-302

Huang G T-J, Sonoyama W, Liu Y, Liu H, Wang S, Shi S (2008) The hidden treasure in apical papilla: the potential role in pulp/dentin regeneration and bioroot engineering. Journal of Endodontics 34, 645-51.

Kim S-J, Shin H-S, Shin S-W (2010) Effect of bone block graft with rhBMP-2 on vertical bone augmentation. International Journal of Oral and Maxillofacial Surgery 39, 883-8.

Komori T, Yagi H, Nomura S et al. (1997) Targeted disruption of Cbfa1 results in a complete lack of bone formation owing to maturational arrest of osteoblasts. Cell 89, 755-64.

Matin K, Senpuku H, Hanada N, Ozawa H, Ejiri S (2003) Bone regeneration by recombinant human bone morphogenetic protein-2 around immediate implants: a pilot study in rats. International Journal of Oral \& Maxillofacial Implants 18, 211-7.

Morsczeck C, Götz W, Schierholz J et al. (2005) Isolation of precursor cells (PCs) from human dental follicle of wisdom teeth. Matrix Biology: Journal of the International Society for Matrix Biology 24, 155-65.

Morsczeck C, Schmalz G, Reichert T E, Völlner F, Galler K, Driemel O (2008) Somatic stem cells for regenerative dentistry. Clinical Oral Investigations 12, 113-8.

Nakashima K, Zhou X, Kunkel G et al. (2002) The novel zinc finger-containing transcription factor osterix is required for osteoblast differentiation and bone formation. Cell 108, 17-29. 
Pagel J I, Deindl E (2011) Early growth response 1--a transcription factor in the crossfire of signal transductioncascades. Indian Journal of Biochemistry \& Biophysics 48, 226-35

Pham L, Bezouglaia O, Camargo P M, Nervina J M, Tetradis S (2007) Prostanoids induce egr1 gene expression in cementoblastic OCCM cells. Journal of Periodontal Research 42, 486-93.

Reumann M K, Strachna O, Lukashova L et al. (2011) Early growth response gene 1 regulates bone properties in mice. Calcified Tissue International 89, 1-9.

Reumann M K, Strachna O, Yagerman S et al. (2011) Loss of transcription factor early growth response gene 1 results in impaired endochondral bone repair. Bone 49, 743-52.

Saugspier M, Felthaus O, Viale-Bouroncle S et al. (2010) The differentiation and gene expression profile of human dental follicle cells. Stem Cells and Development 19, 707-17.

Sonoyama W, Liu Y, Fang D et al. (2006) Mesenchymal stem cell-mediated functional tooth regeneration in swine. PloS One 1, e79.

Sonoyama W, Liu Y, Yamaza T et al. (2008) Characterization of the apical papilla and its residing stem cells from human immature permanent teeth: a pilot study. Journal of Endodontics 34, 166-71.

Sukhatme V P, Cao X M, Chang L C et al. (1988) A zinc finger-encoding gene coregulated with c-fos during growth and differentiation, and after cellular depolarization. Cell 53, 37-43. Swirnoff AH, Milbrandt J (1995) DNA-binding specificity of NGFI-A and related zinc finger transcription factors. Molecular and Cellular Biology 15, 2275-87

Ten Dijke P, Fu J, Schaap P, Roelen B A J (2003) Signal transduction of bone morphogenetic proteins in osteoblast differentiation. Journal of Bone and Joint Surgery. American Volume 85-A Suppl 3, 34-38. 
Viale-Bouroncle S, Felthaus O, Schmalz G, Brockhoff G, Reichert T E, Morsczeck C (2012) The Transcription Factor DLX3 Regulates the Osteogenic Differentiation of Human Dental Follicle Precursor Cells. Stem Cells and Development 21, 1936-47

Viale-Bouroncle S, Gosau M, Morsczeck C (2013) NOTCH-1 signaling regulates the BMP2/DLX-3 directed osteogenic differentiation of dental follicle cells. Biochemical and Biophysical Research Communications 443, 500-4

Wang F L, Connor J R, Dodds R A et al. (2000) Differential expression of egr-1 in osteoarthritic compared to normal adult human articular cartilage. Osteoarthritis and Cartilage / OARS, Osteoarthritis Research Society 8, 161-9.

Winer J, Jung C K, Shackel I, Williams P M (1999) Development and validation of real-time quantitative reverse transcriptase-polymerase chain reaction for monitoring gene expression in cardiac myocytes in vitro. Analytical Biochemistry 270, 41-9.

Link zur Originalpublikation:

http://onlinelibrary.wiley.com/doi/10.1111/iej.12299/abstract;jsessionid=3AB81CAC521C48 $\underline{237552765382 \mathrm{E} 790 \mathrm{~F} 8 . \mathrm{f0} 1 \mathrm{t} 01}$ 


\section{Lebenslauf}

\section{Persönliche Angaben}

Name: Thomas Preß

Geburtsdatum: 10.05.1985

Geburtsort: Regensburg

\section{Ausbildungen und berufliche Laufbahn}

11/2014 Abschluss Staatsexamen Zahnmedizin an der Universität Regensburg 10/2009 - 07/2014 Studium der Zahnmedizin

02/2008 - 09/2009 Berufstätigkeit als Zahntechniker

09/2005 - 01/2008 Berufsausbildung zum Zahntechniker

09/2004 - 07/2005 Zivildienst

06/2004 Abitur Albrecht-Altdorfer-Gymnasium Regensburg 